\title{
Stability and sensory assessment of emulsions containing propolis extract and/or tocopheryl acetate
}

\author{
Gisele Mara Silva Gonçalves ${ }^{1, *}$, Silvana Mariana Srebernich², Jacqueline Alves de Macedo Souza ${ }^{1}$ \\ ${ }^{1}$ Faculty of Pharmaceutical Sciences, Pontifical Catholic University of Campinas, ${ }^{2}$ Faculty of Nutrition, Pontifical Catholic \\ University of Campinas
}

\begin{abstract}
The prevention of skin aging has been one of the main aims of cosmetic products. Propolis and tocopheryl acetate can be promising substances because of their antioxidant properties. In this study, propolis extract was obtained and associated with tocopheryl acetate in a cream formulation, which then underwent stability and sensory assessment. The formulation containing propolis extract and tocopheryl acetate proved to be stable in the preliminary stability study, demonstrating gradual darkening and slight $\mathrm{pH}$ decrease when subjected to $60^{\circ} \mathrm{C}$ for 28 days, but showing stability on rheological study. In the sensory analysis, the formulation containing these two components was preferred by the product testers over the base cream and creams containing propolis extract or tocopheryl acetate alone. In conclusion, given the stability of the formulation and the preference of the product testers for this formulation, this association proved promising for use in cosmetic formulations.
\end{abstract}

Uniterms: Antioxidant/use in cosmetic formulations. Cosmetics/sensory analysis. Propolis/extract/use in cosmetics. Tocopheryl acetate/use in cosmetics.

\begin{abstract}
A prevenção do envelhecimento cutâneo tem sido um dos principais focos dos produtos dermocosméticos. A própolis contém substâncias com atividade antioxidante, bem como o acetato de tocoferila é conhecido por apresentar esta atividade. Porém, a própolis apresenta odor muito característico e intenso, que pode interferir no sensorial do produto. Assim, no presente trabalho, obteve-se o extrato de própolis, que foi associado ao acetato de tocoferila em uma formulação de uso tópico, que foi avaliada quanto à estabilidade e às características sensoriais. Conduziu-se um estudo de estabilidade, no qual as formulações contendo ambos os compostos apresentaram escurecimento gradual e ligeira queda no $\mathrm{pH}$ após 28 dias sob $60^{\circ} \mathrm{C}$, tendo sido estável no estudo reológico. Na análise sensorial, realizada com 28 provadores, a formulação contendo extrato de própolis em associação com acetato de tocoferila foi a preferida, quando comparada com o creme base e o creme contendo somente extrato de própolis ou acetato de tocoferila. Em conclusão, devido à preferência dos provadores e ao estudo de estabilidade, a associação de extrato de própolis e de acetato de tocoferila mostrou ser promissora para uso em produtos dermocosméticos.
\end{abstract}

Unitermos: Antioxidantes/uso em cosméticos. Cosméticos/análise sensorial. Própolis/extrato/uso cosmético. Acetato de tocoferila/uso cosmético.

\section{INTRODUCTION}

Cosmetics often contain photoprotective substances and also antioxidants, which are used to protect against free radicals which can be generated by Sun exposure. Some of this damage is cumulative, so both young and old skin need proper protection (Borges et al., 2002; Chung,

*Correspondence: G. M. S. Gonçalves. Faculdade de Ciências Farmacêuticas, Pontifícia Universidade Católica de Campinas. Av. John Boyd Dunlop, s/n Jardim Ipaurussurama - 13059-900 -Campinas - SP, Brazil. E-mail: gmsg@ puc-campinas.edu.br
2003). The effects of exposure to solar radiation can be acute or chronic and lead to changes in cellular DNA.

Vitamin E or $\alpha$-tocopherol is naturally present in human skin where it has the important role of protecting against reactive oxygen species. Tocopherol esters are generally more stable, which allows their use in topic formulations, such as emulsions. Tocopheryl acetate has been widely used in this type of formulation since it can penetrate the skin and be converted to the tocopherol form (Norkus, Bryce, Bhagavan, 2008).

Many studies are underway to assess the stability 
of formulations containing vitamin $\mathrm{E}$ or to confirm the efficacy of tocopheryl acetate in improving photoaged skin (Almeida et al., 2010; Gaspar, Campos, 2007; Chiu, Kimball, 2003, Guaratini et al., 2006). Gaspar and Campos (2007) studied formulations containing sunscreen associated with vitamins $\mathrm{A}, \mathrm{C}$ and $\mathrm{E}$ on the skin of hairless mice which was exposed to ultraviolet radiation and concluded that these vitamins, in association with photoprotective substances, play an important role in protecting the skin.

Another component of interest is propolis, which is a resin obtained mainly from the European bee Apis mellifera (Salatino et al., 2005). Its chemical composition is complex and varies according to the biodiversity of the region. Flavonoids, aromatic acids, fatty acids, phenols, terpenoids, aldehydes, alcohols, aliphatic acids and esters, amino acids, sugars, vitamins and minerals are among the components found in propolis (Marcucci, 1995). Propolis flavonoids have been studied by researchers worldwide (Havsteen, 2002) and some authors consider them the key components to be assessed for propolis quality control (Kosalec et al.., 2005).

Propolis extract can be used in cosmetic products for different purposes (Ramos, Miranda, 2007). The use of anti-aging cosmetics should be daily since the effects are generally seen in the long term (Campos et al., 2008). Thus, for consumers to use these products correctly, the products need to be attractive and promote a feeling of well-being for users. For example, the color, odor and feel of the product on the skin must be pleasant for the consumer. Furthermore, their efficacy and safety must be proven by proper methods and their applications approved by regulatory agencies (Faria, Yotsuyanagi, 2002; Engen, 1991). Since propolis has a very characteristic and strong odor, the addition of its extract in formulations could confer its color and particularly its odor, to the product, and affect the acceptance of the product by the consumer. Hence, it is evident that acceptance by the consumer needs to be verified.

The association between propolis extract and tocopheryl acetate in a formulation for topical use could be attractive since users could benefit from the properties of both (Buchli, 2002; Havsteen, 2002; Salatino et al., 2005; Salgado-Santos et al., 2005).

The objectives of the present study were to produce a propolis extract for use in skin care products and to determine the physico-chemical and physical stability of a formulation containing an association between the propolis extract produced and tocopheryl acetate and finally, to subject this formulation to sensory analysis.

\section{MATERIAL AND METHODS}

\section{Propolis extract}

Brazilian green propolis was pulverized, transferred to a paper shell and placed in a Soxhlet extractor for 24 hours with ethanol $96 \%$. Twenty grams of propolis was used for every $400 \mathrm{~mL}$ of ethanol (Araújo et al.., 2002).

\section{Formulations}

\section{Materials}

Tocopheryl acetate 98\% was purchased from Sigma (St. Lowis, MO, USA), Nikkolipid ${ }^{\mathrm{TM}}$ (batyl alcohol, stearic acid, lecithin, caprylic/capric triglyceride) from Nikko Chemicals (Tokyo, Japan), Phenova ${ }^{\mathrm{TM}}$ (phenoxyethanol and parabens) from Croda (Campinas, SP, Brazil), isopropyl myristate, butylated hydroxytoluene and tetrasodium EDTA from Labisynth (Diadema, SP, Brazil), hydroxyethyl cellulose from Galena (Campinas, SP, Brazil) and propylene glycol from Volp (Osasco, SP, Brazil). Distilled water was further purified with a Milli-Q System (Millipore, Bedford, MA, USA).

An O/W emulsion was prepared for addition to propolis and/or tocopheryl acetate. The formulation contained (w/w) 1.5\% hydroxyethyl cellulose; $3.0 \%$ batyl alcohol, stearic acid, lecithin, caprylic/capric triglyceride; $3.0 \%$ isopropyl myristate; $5.0 \%$ propylene glycol; $0.6 \%$ phenoxyethanol and parabens; $0.1 \%$ butylated hydroxytoluene; $0.1 \%$ tetrasodium EDTA and water to $100 \%$.

Propolis extract was added to the cream to a final concentration of $5 \%$ or tocopheryl acetate to a final concentration of $2 \%(\mathrm{w} / \mathrm{w})$. The assessed formulations were: A (vehicle); $\mathrm{B}$ (vehicle plus propolis extract); $\mathrm{C}$ (vehicle plus tocopheryl acetate) and $\mathrm{D}$ (vehicle plus propolis extract and tocopheryl acetate).

\section{Preliminary stability study}

Formulations A to D were stored in PVC tubs ( $37 \mathrm{~mm}$ in diameter $\times 29 \mathrm{~mm}$ deep) and in Borel glass at 40,60 and $\sim 25^{\circ} \mathrm{C}$ for up to 28 days.

Appearance, $\mathrm{pH}$, color, odor and viscosity were assessed at 7-day intervals as described in the Guide for the Quality Control of Cosmetic Formulations, a publication by the National Health Surveillance Agency (in Portuguese, Agência Nacional de Vigilância Sanitária, ANVISA) an autonomous department of the Brazilian government (Guia, 2007). The pH of the formulations diluted with water to one-tenth of their original concentrations was determined by a Digimed $\mathrm{pH}$ meter. Color and appearance of the formulations were assessed by a visual method and 
olfaction. These assessments took into consideration the initial attributes of the formulations and changes that may or may not have occurred during the study period.

Physical stability was assessed by rheological determinations done on a RTV Brookfield rotational viscometer (Stoughton, MA, USA). Viscosity parameters were determined at $25^{\circ} \mathrm{C}$ using a number 6 spindle for each sample $24 \mathrm{~h}$ after preparation, and at regular intervals over the storage period. Samples were tested with rotation speeds that increased progressively (1-10 rpm). Each reading was done 60 seconds after the new rotation speed.

\section{Study protocol}

The research ethics committee of the Pontifical University of Campinas approved the study under protocol number 697/2007.

\section{Sample preparation and sensory panel}

The panel consisted of 28 female volunteers who had no training in sensory assessment techniques.

The test was done in sensory cabin with red lighting. Each volunteer had their own cabin. These cabins were designed for sensory analysis of products in general. They are ventilated, free from strong odors, white, allow the volunteer to sit in a comfortable position and employ red lighting to prevent the color of the product from influencing the tester. The volunteer is allowed to remain in the cabin for as long as necessary.

Before the tests began, the samples were numbered with random 3-digit numbers and offered in a random sequence to each product tester, to prevent the tester from identifying the samples. The temperature of all samples distributed to the testers was the same (room temperature) and the samples were fresh. The product testers were instructed to apply a small amount of each of the formulations in different areas on the back of their hands to assess their characteristics. Subsequently, they received the formulations and an analysis form containing instructions and closed questions for them to compare the formulations and indicate their oiliness, stickiness, feel and spreadability. The volunteers also reported which formulation they preferred.

\section{RESULTS AND DISCUSSION}

The use of ethanol to extract the phenolic components of interest to this study from propolis was based on published studies (Buriol et al., 2009; Cunha et al., 2004). The obtained propolis extract was added to a cre- am formulation, associated or otherwise with tocopheryl acetate. Four products were created, some of which had $5 \%$ propolis extract content associated or otherwise with $2 \%$ tocopheryl acetate content. These concentrations were based on the studies of many authors (Chiu, Kimball, 2003; Lexis et al., 2006; Maia Campos et al., 2007) and the purpose of using high concentrations, especially of propolis extract, was to transfer its odor to the product and see how this odor affected the acceptance of the product by the product testers.

The base cream formulation was developed to contain a hydrophilic polymer in its composition that helps stabilize the emulsion, avoids excess oiliness and makes the product suitable for a tropical climate. The initial $\mathrm{pH}$ of the formulations was close to the physiological $\mathrm{pH}$ of the human skin (Silva, Maia Campos, 2000a, b).

Some changes were observed in $\mathrm{pH}$ over time. Storage temperature also affected the properties of the formulations, especially those stored at $40{ }^{\circ} \mathrm{C}$ and $60{ }^{\circ} \mathrm{C}$ (Figure 1).

Some changes were observed in the appearance, color and odor of the formulations over time and under different temperatures, especially in those stored at higher temperatures (Table I).

In the accelerated stability study, the formulations were stored under different temperatures and assessed during a 28-day period. In general, the $\mathrm{pH}$ values decreased, especially in formulations containing propolis extract (Figure 1). These variations may have been caused by hydrolysis reactions or even oxidation of the preparation components and commonly occur in accelerated stability studies (Baby et al., 2007; Manfio et al., 2007; Mendonça et al., 2009; Pianovski et al., 2008). Since these changes were observed mainly in the formulations containing the active ingredients, this suggests that instability was due to these components, which affected the integrity of the formulation.

The color (white) and characteristic odor of the base formulation (A) remained unchanged during the assessment period. Formulations $\mathrm{B}$ and $\mathrm{C}$ presented no changes after the 28-day storage period at room temperature, while formulations A and D presented decreased $\mathrm{pH}$. Regarding aspect, all formulations stored at room temperature retained their baseline characteristics after the storage period of 28 days. However, after 14 days of storage at $60^{\circ} \mathrm{C}$, there was visible dryness on the surface of the product, with the formation of a peel. Formulation B was initially yellow because of the addition of propolis extract; only the sample stored at $60^{\circ} \mathrm{C}$ presented gradual darkening and intensification of odor. Formulation $\mathrm{C}$ was initially white and when stored at $60^{\circ} \mathrm{C}$, gradually darkened and formed a crust due 


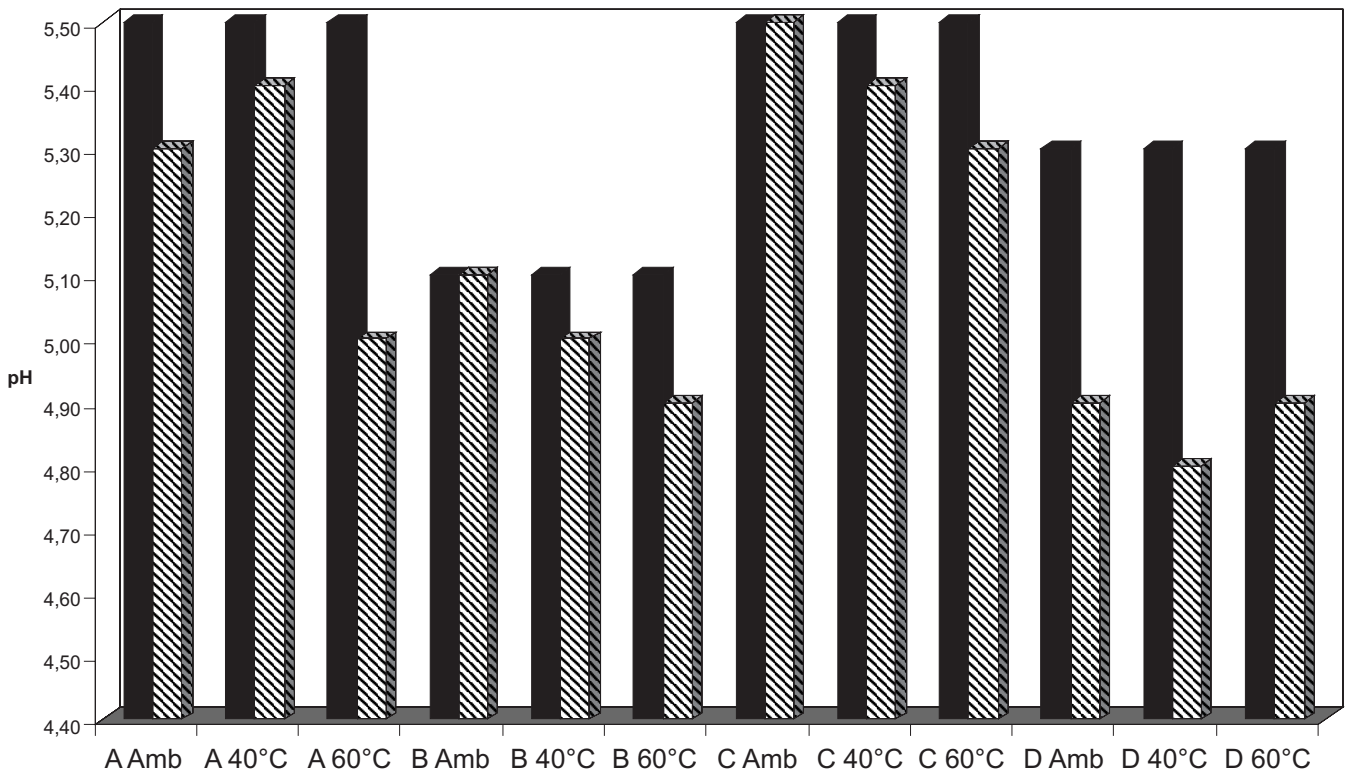

- Initial \$After 28 days

FIGURE 1 - pH of formulations (baseline and after a 28-day period) at room temperature, $40{ }^{\circ} \mathrm{C}$ and $60{ }^{\circ} \mathrm{C}$ (A: vehicle; $\mathrm{B}$ : vehicle plus propolis extract; $\mathrm{C}$ : vehicle plus tocopheryl acetate; D: vehicle plus propolis extract and tocopheryl acetate).

TABLE I - Appearance, color and odor of formulations over a 28 -day period at room temperature $\left(25^{\circ} \mathrm{C}\right), 40{ }^{\circ} \mathrm{C}$ and $60{ }^{\circ} \mathrm{C}$

\begin{tabular}{|c|c|c|c|c|c|c|}
\hline \multirow[t]{2}{*}{ Formulation } & \multirow{2}{*}{$\begin{array}{c}\text { Storage } \\
\text { Temperature } \\
\left({ }^{\circ} \mathrm{C}\right)\end{array}$} & \multicolumn{5}{|c|}{ Appearance, color and odor } \\
\hline & & Initial & 7 days & 14 days & 21 days & 28 days \\
\hline \multirow[t]{3}{*}{ A (vehicle) } & 25 & $\mathrm{CO}$, white & $\mathrm{CO}$, white & $\mathrm{CO}$, white & $\mathrm{CO}$, white & $\mathrm{CO}$, white \\
\hline & 40 & - & $\mathrm{CO}$, white & $\mathrm{CO}$, white & $\mathrm{CO}$, white & $\mathrm{CO}$, white \\
\hline & 60 & - & $\mathrm{CO}$, white & $\begin{array}{l}\text { CO, white, } \\
\text { crust }\end{array}$ & $\begin{array}{l}\mathrm{CO}, \text { white, } \\
\text { crust }\end{array}$ & $\begin{array}{l}\mathrm{CO} \text {, white, } \\
\text { thick crust }\end{array}$ \\
\hline \multirow{3}{*}{$\begin{array}{l}\text { B (vehicle plus propolis } \\
\text { extract) }\end{array}$} & 25 & $\mathrm{CO}$, yellow & $\mathrm{CO}$, yellow & $\mathrm{CO}$, yellow & $\mathrm{CO}$, yellow & $\mathrm{CO}$, yellow \\
\hline & 40 & - & $\mathrm{CO}$, yellow & $\mathrm{CO}$, yellow & $\mathrm{CO}$, yellow & $\mathrm{CO}$, yellow \\
\hline & 60 & - & $\begin{array}{c}\text { Odorous, dark } \\
\text { yellow }\end{array}$ & $\begin{array}{c}\text { Odorous, dark } \\
\text { yellow }\end{array}$ & $\begin{array}{c}\text { Odorous, dark } \\
\text { yellow }\end{array}$ & $\begin{array}{l}\text { Odorous, dark } \\
\text { yellow, thick } \\
\text { crust }\end{array}$ \\
\hline \multirow{3}{*}{$\begin{array}{l}\mathrm{C} \text { (vehicle plus } \\
\text { tocopheryl acetate) }\end{array}$} & 25 & $\mathrm{CO}$, white & $\mathrm{CO}$, white & $\mathrm{CO}$, white & $\mathrm{CO}$, white & $\mathrm{CO}$, white \\
\hline & 40 & - & $\mathrm{CO}$, white & CO, white & $\mathrm{CO}$, white & $\mathrm{CO}$, white \\
\hline & 60 & - & $\mathrm{CO}$, yellow & $\begin{array}{l}\mathrm{CO}, \text { yellow, } \\
\text { crust }\end{array}$ & $\begin{array}{l}\mathrm{CO}, \text { yellow, } \\
\text { crust }\end{array}$ & $\begin{array}{l}\mathrm{CO} \text {, brown, } \\
\text { thick crust }\end{array}$ \\
\hline \multirow{3}{*}{$\begin{array}{l}\mathrm{D} \text { (vehicle plus propolis } \\
\text { extract and tocopheryl } \\
\text { acetate) }\end{array}$} & 25 & $\mathrm{CO}$, yellow & $\mathrm{CO}$, yellow & $\mathrm{CO}$, yellow & $\mathrm{CO}$, yellow & $\mathrm{CO}$, yellow \\
\hline & 40 & - & $\mathrm{CO}$, yellow & $\mathrm{CO}$, yellow & $\mathrm{CO}$, yellow & $\mathrm{CO}$, yellow \\
\hline & 60 & - & $\begin{array}{l}\text { Odorous, } \\
\text { yellow }\end{array}$ & $\begin{array}{l}\text { Odorous, } \\
\text { yellow, crust }\end{array}$ & $\begin{array}{l}\text { Odorous, } \\
\text { yellow, crust }\end{array}$ & $\begin{array}{l}\text { Odorous, yellow, } \\
\text { thick crust }\end{array}$ \\
\hline
\end{tabular}

A: vehicle; B: vehicle plus propolis extract; C: vehicle plus tocopheryl acetate; D: vehicle plus propolis extract and tocopheryl acetate; $\mathrm{CO}=$ characteristic odor. 
to dryness. Its odor remained unchanged. Formulation D was initially yellow but storage at $60^{\circ} \mathrm{C}$ darkened it over time, intensified its odor and formed a crust. According to the Guidance for Industry: Q1A(R2) Stability Testing of New Drug Substances and Products (2003), color change is a relevant alteration that must be considered in stability studies. The color of the product may or may not change during the shelf-life test and if it does so, this indicates that the product is unstable. In conclusion, the observed changes were due to the storage conditions.

Rheological parameters were used to assess the physical stability of the formulations since rheological studies can provide information on physical stability during shelf life and performance at time of use (Gaspar, Maia Campos, 2003; Tadros, 2004).

The apparent viscosity was determined at the maximum gradient strength when viscosity and rheological behavior of the formulations as a function of time and storage temperature were assessed (Table II and Figure 2).

In cosmetology, products have different rheological

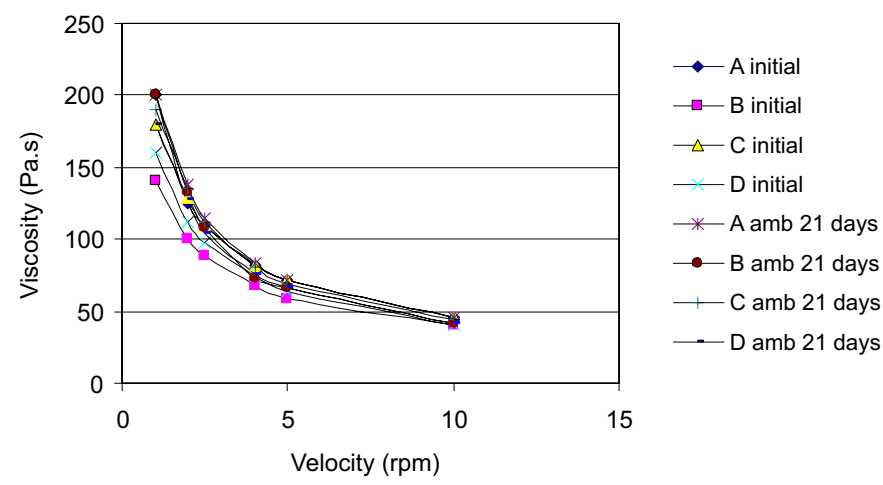

FIGURE 2 - Rheogram of formulations 24 hours after preparation and after 21 days stored at room temperature and at $60{ }^{\circ} \mathrm{C}$. Values expressed in centipoise. A: vehicle; $B$ : vehicle plus propolis extract; $C$ : vehicle plus tocopheryl acetate; $D$ : vehicle plus propolis extract and tocopheryl acetate. behaviors that affect both the use of the product by the consumer (for example, the amount of effort necessary to spread the product onto the skin) and the manufacturing process (mixing and packaging methods) (Almeida, Bahia, 2003). In other words, rheological studies should be done during both development and production phases of a product. The studies are also very useful for quality control (Barnes, 1994; Barnes, 1997; Bentley, 1999).

In the present study, the formulations that contained propolis extract presented decreased initial viscosity where the addition of tocopheryl extract caused a slight change in initial viscosity. Comparison of the rheograms for all formulations reveals that all formulations present pseudoplastic behavior, since viscosity decreased with higher rotation speeds, thereby increasing shear stress. Pseudoplastic behavior is desirable in formulations of topical use because it improves spreading of the product on the skin, among other factors (Gaspar, Maia Campos, 2003).

The results of the rheological studies obtained for storage day 21 were discarded since a very thick crust was present in the formulations at storage day 28 . The formulation under this crust became very liquid, thus making it impossible to carry out this assessment. Therefore, only the values obtained up until storage day 21 were considered. The formulation that presented the greatest variation in viscosity was formulation $\mathrm{D}$ after 21 days of storage at $60{ }^{\circ} \mathrm{C}$. It presented the lowest viscosity values, indicating gradual spoilage of the product secondary to the high temperature. The results obtained for viscosity, $\mathrm{pH}$ and appearance over time were all coherent.

A possible alternative to improve the stability of these formulations is changing the packaging. Plastic jars suitable for creams were used in this study. However, this type of packaging may not be ideal for maintaining the stability of a formulation that requires extra care. Packaging that could possibly improve the stability of the product is the aluminum tube used for pharmaceutical products.

TABLE II - Apparent viscosity (mPa.s) of formulations stored at room temperature and at $60{ }^{\circ} \mathrm{C}$, over a 21 -day period calculated at maximum gradient strength

\begin{tabular}{lcccccccc}
\hline & \multicolumn{6}{c}{ Apparent Viscosity (mPa.s) at peak shear } \\
\cline { 2 - 8 } Formulation & \multirow{2}{*}{ Initial } & 7 days & 14 days & 21 days & 28 days & 7 days & 14 days & 21 days \\
\cline { 2 - 8 } & 45600 & 44500 & 44600 & 46000 & 46000 & 45000 & 45000 & 37000 \\
A & 45000 & 44500 & 43000 & 41900 & 41500 & 35500 & 34500 & 25600 \\
B & 45500 & 45000 & 42500 & 43800 & 44500 & 45000 & 45000 & 43600 \\
C & 41000 & 39500 & 38700 & 40500 & 41400 & 40000 & 34000 & 25000 \\
D & & &
\end{tabular}

A: vehicle; B: vehicle plus propolis extract; C: vehicle plus tocopheryl acetate; D: vehicle plus propolis extract and tocopheryl acetate. 
Propolis presents a unique odor and therefore a sensory analysis is necessary to assess consumer acceptance. Since the formulations had different colors, the analyses were done in cabins with appropriate red lighting to prevent the volunteers from noticing this difference.

The sensory test was performed to determine whether propolis ethanol extract and tocopheryl acetate affects product tester acceptance of the formulation containing these two ingredients (Figure 3).

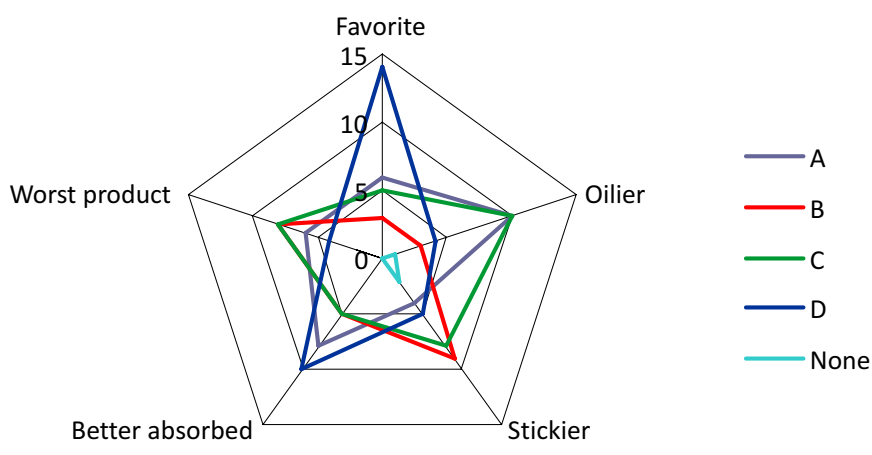

FIGURE 3 - Sensory characteristics of formulations according to 28 product testers. (A: vehicle; B: vehicle plus propolis extract; $C$ : vehicle plus tocopheryl acetate; D: vehicle plus propolis extract and tocopheryl acetate).

When the product testers were asked about what they felt when they applied each formulation onto the back of their hands, both formulations $\mathrm{A}$ and $\mathrm{C}$ (vehicle and vehicle plus tocopheryl acetate) were considered the oiliest by $35.7 \%$ of the product testers. Formulations B and $\mathrm{C}$ (containing propolis extract or tocopheryl acetate, respectively) were considered the stickiest by 28.6 and $32.1 \%$ of the product testers, respectively. Formulation $\mathrm{D}$ (containing propolis extract associated with tocopheryl acetate) was preferred by $46.4 \%$ of the product testers. This result was confirmed when the product testers were asked which formulation they liked least: formulations A, B and C were each cited by $28.6 \%$ of the product testers, while formulation $\mathrm{D}$ was cited by only $10.7 \%$ of product testers.

When analyzing these results, it is necessary to take into account that the base of all formulations was the same and that the difference was in terms of the presence or otherwise of propolis extract and/or tocopheryl acetate. It is also important to point out that an untrained group of product testers was used, that is, the volunteers were not used to assessing cosmetic products and already had established preferences with regard to skin care products. The objective was to assess the acceptability of the formulations under study.

Under these experimental conditions, the results suggest that the sensations of oiliness and stickiness promoted by the formulations were determinants in the answers given by the product testers. Thus, the association between propolis extract and tocopheryl acetate contributed to minimize these sensations, i.e. they reduced the sensation of oiliness and stickiness attributed to the product when applied to the skin. It is important to state that the formulation of the base cream for all the formulations was developed to be an easy-to-spread product with a mild odor, so as not to influence the results.

The volunteers were not asked about the odor of propolis. Formulations $\mathrm{A}$ and $\mathrm{C}$ did not contain propolis extract yet did not receive good reviews from the volunteers. Formulation B contained only propolis extract and also did not receive good reviews. Finally, formulation D, which contained both propolis extract and tocopheryl acetate, received the best reviews from the volunteers. Thus, in the global assessment, odor was apparently not a determinant in the preference of the product testers. However, this study investigated only a single administration of the product where results could vary if the study investigated daily use of the product over a period of time.

Our results indicate that the combination of active ingredients used in this study produced different sensations, and were positive and accepted by the volunteers. In fact, the goal of this association was to prevent aging by the use of synergism and the results suggested that the sensory profile of the product also improved, probably because the oiliness of tocopheryl acetate reduced the stickiness of the propolis extract, making it the favorite formulation.

Finally, cosmetic formulators must consider not only the efficacy and safety of the formulation, but also carry out sensory panels before launching products on the market. The selection of active substances has to be meticulous so that their use on the skin for a given time to obtain the desired effects is effective in preventing skin aging. During the selection of the formulation constituents, it is important to evaluate the components of the vehicle properly and to consider the sensory properties conferred by the selected active ingredients, which are of fundamental importance for consumer acceptance and preference.

\section{CONCLUSION}

According to the results of this study, the stability of the tested formulations determined by the preliminary stability study was reasonable. The sensory panel showed that the studied compounds affected the characteristics of the formulations and revealed that the product testers preferred the formulation which contained a combination of propolis extract with tocopheryl acetate. 


\section{ACKNOWLEDGMENTS}

The authors would like to thank the Pontifical Catholic University of Campinas for sponsoring the study.

\section{REFERENCES}

ALMEIDA, I. F.; BAHIA, M. F. Reologia: interesse e aplicações na área cosmético-farmacêutica. Cosm. Toil., v.15, n.3, p.96-100, 2003.

ALMEIDA, M. M.; LIMA, C. R. R. C.; QUENCA- GUILLEN, J. S.; FILHO, E. M.; MERCURI, L. P.; SANTORO, M. I. R. M.; KEDOR-HACKMANN, E. R. M. Stability evaluation of tocopheryl acetate and ascorbyl tetraisopalmitate in isolation and incorporated in cosmetic formulations using thermal analysis. Braz. J. Pharm. Sci., v.46, n.1, p.129-134, 2010 .

ARAUjO, C. E. P.; SHIMIZU, M. T.; CUNHA, I. B.; MARCUCCI, M. C.; RAMOS, O. H. P.; SAWAYA, A.C.H.F. Análise química, toxicológica e antiulcerogênica preliminar de uma amostra de própolis da região do Paraná. Rev. Lecta, v.1, n.20, p.47-52, 2002.

BABY, A. R.; MIGLIATO, K. F.; MACIEL, C. P. M.; ZAGUE, V.; PINTO, C. A. S. O.; SALGADO, H. R. N.; KANEKO, T. M.; VELASCO, M. V. R. Accelerated chemical stability data of $\mathrm{O} / \mathrm{W}$ fluid emulsions containing the extract of Trichilia catigua Adr. Juss (and) Ptychopetalum olacoides Bentham. Braz. J. Pharm. Sci., v.43, n.3, p.405-412, 2007.

BARNES, H. A. Rheology of emulsions - a review. Colloids Surfaces A: Physicochem. Eng. Aspects, v.91, p.89-95, 1994.

BARNES, H. A. Thixotropy - a review. J. Non-Newton. Fluid. v.70, n.1-2, p.1-33, 1997.

BENTLEY, M.V.L.B.; MARCHETTI, J.M.; RICARDO, N.; ALI-ABID, Z.; COLLETT, J.H. Influence of lecithin on some physical chemical properties of poloxamer gels: rheological, microscopic and in vitro permeation studies. Int. J. Pharm., v.193, n.1, p.49-55, 1999.

BORGES, V. L.; RANGEL, I.; CORREIA, M. A. Fotoproteção. Cosm. Toil., v.14, n.6, p.88-95, 2002.

BUCHLI, L. Radicais livres e antioxidantes. Cosm. Toil., v.14, n.2, p.54-57, 2002.
BURIOL, L.; FINGER, D.; SCHMIDT, E. M.; SANTOS, J. M. T.; ROSA, M. R.; QUINÁIA, S. P.; TORRES, Y. R.; SANTA, H. S. D.; PESSOA, C.; MORAES, M. O.; COSTALOTUFO, L. V.; FERREIRA, P. M. P.; SAWAYA, A. C. H. F.; EBERLIN, M. N. Composição química e atividade biológica de extrato oleoso de própolis: uma alternativa ao extrato etanólico. Quim. Nova, v.32, n.2, p.296-302, 2009.

CAMPOS, P. M. B. G.; GONÇALVES, G. M. S.; GASPAR, L. $\mathrm{R}$. In vitro antioxidant activity and in vivo efficacy of topical formulations containing vitamin $\mathrm{C}$ and its derivatives studied by non-invasive methods. Skin Res. Tech., v.14, n.3, p.376-380, 2008.

CHIU, A.; KIMBALL, A.B. Topical vitamins, minerals and botanical ingredients as modulators of environmental and chronological skin damage. Br. J. Dermatol., v.149, n.4, p.681-691, 2003.

CHUNG, J.H. Photoaging in Asians. Photoderm. Photoimm. Photomed., v.19, n.3, p.109-121, 2003.

CUNHA, I. B. S.; SAWAYA, A. C. H. F.; CAETANO, F. M.; SHIMIZU, M. T.; MARCUCCI, M. C.; DREZZA, F. T.; POVIA, G. S.; CARVALHO, P. O. Factors that influence the yield and composition of brazilian propolis extracts. $J$. Braz. Chem. Soc., v.15, n.6, p.964-970, 2004.

ENGEN, T. Odor sensation and memory. New York: Praeger Publisheres, 1991. 146 p.

FARIA, E. V.; YOTSUYANAGI, K. Técnicas de análise sensorial. Campinas: ITAL/LAFISE, 2002. 116 p.

GASPAR, L. R. C.; MAIA CAMPOS, P. M. B. G. Rheological behavior and the SPF of sunscreens. Int. J. Pharm., v.250, n.1, p.35-44, 2003

GASPAR, L. R.; CAMPOS, P. M. B. G. Photostability and efficacy studies of topical formulations containing UVfilters combination and vitamins A, C and E. Int. J. Pharm., v.343, n.1, p.181-189, 2007.

GUARATINI, T.; GIANETI, M.D.; MAIA CAMPOS, P.M.B.G. Stability of cosmetic formulations containing esters of Vitamins E and A: chemical and physical aspects. Int. J. Pharm., v.327, n.1, p.12-16, 2006. 
GUIDANCE FOR INDUSTRY: Q1A(R2) Stability testing of new drug substances and products. Rockville, Center for Biologics Evaluation and Research Food and Drug Administration. Rockville: ICH, 2003. 25 p. Available at: $<$ http://www.fda.gov/downloads/RegulatoryInformation/ Guidances/ucm128204.pdf > . Accessed on: 01 oct. 2010.

\section{GUIA DE ESTABILIDADE DE PRODUTOS COSMÉTICOS.} Séries Temáticas, 2004. Available at: $<\mathrm{http} / /$ www.anvisa. gov.br/divulga/public/series/cosmeticos.pdf $>$. Accessed on: 01 oct. 2010.

HAVSTEEN, B. H. The biochemistry and medical significance of the flavonoids. Farmacol. Terap., v.96, n.2, p.67-202, 2002.

KOSALEC, I.; PEPELJNJAK, S.; BAKMAZ, M.; VLADIMIR, S. Flavonoid analysis and antimicrobial activity of commercially available propolis products. Acta Pharm., v.55, n.4, p.423-430, 2005.

LEE, E. R.; KANG, G.H.; CHO, S.G. Effect of flavonoids on human health: old subjects but new challenges. Rec. Pat. Biotech., v.1, n.2, p.139-150, 2007.

LEXIS, L. A.; FASSETT, R. G.; COOMBES, J. S. Tocopherol and a-Lipoic Acid Enhance the Erythrocyte Antioxidant Defence in Cyclosporine A-Treated Rats. Basic Clin. Pharmacol. Toxicol.. v.98, n.1, p.68-73, 2006.

MAIA CAMPOS, P M. B. G.; GIANETI, M.D.; KANASHIRO, A.; LUCISANO-VALIM, Y. M.; GASPAR, L.R. In vitro antioxidant and in vivo photoprotective effects of an association of bioflavonoids with liposoluble vitamins. Photochem. Photobiol., v.82, n.3, p.683-688, 2007.

MANFIO, J. M.; DAL'MASO, A.; PUGENS, A. M.; JUNIOR, L. B.; STEPPE, M. Determinação do prazo de validade do medicamento carbocisteína xarope através do método de Arrhenius. Rev. Bras. Cienc. Farm., v.43, n.4, p.563-570, 2007.

MARCUCCI, M.C. Propolis, chemical composition, biological properties and the therapeutic activity. Apidologie, v.26, n.2, p.83-99, 1995.

MEILGAARD, M.; CiVille, G. V.; CARR, B. T. Sensory evaluation techniques. 3.ed. Boca Raton: CRC Press, 1999. $387 \mathrm{p}$.
MENDONÇA, C.C.; SILVA, I.C.L.; RODRIGUES, K.A.; CAMPOS, M.A.L.; MEDEIROS, M.C.M.; CASTELI, V.C.; FERRARI, M., MUSIS, C.R.; MACHADO, S.R.P. Emulsões O/A contendo Cetoconazol 2,0\%: avaliação da estabilidade acelerada e estudos de liberação in vitro. Rev. Ciênc. Farm. Bás. Apl., v.30, n.1, p.35-46, 2009.

NORKUS, E. P.; BRYCE; G. F.; BHAGAVAN, H. N. Uptake and bioconversion of $\alpha$-tocopheryl acetate to $\alpha$-tocopherol in skin of hairless mice. Photochem. Photobiol., v.57, n.4, p.613-615, 2008.

PIANNOVSKI, A. R.; VILELA, A. F. G.; SILVA, A. A. S.; LIMA, C. G.; SILVA, K. K.; CARVALHO, V. F. M.; MUSIS, C. R.; MACHADO, S. R. P.; FERRARI, M. Development and evaluated the physical stability $\mathrm{O} / \mathrm{W}$ emulsions containing babassu oil (Orbignya oleifera). Rev. Bras. Cienc. Farm., v.44, n.2, p.249-259, 2008.

RAMOS, A. F. N., MIRANDA J. L. Propolis: a review of its anti-inflammatory and healing actions. J. Venom. Anim. Toxins incl. Trop. Dis., v.13, n.4, p.697-710, 2007.

SALATINO, A.; TEIXEIRA, E. W.; NEGRI, G.; MESSAGE-D. Origin and chemical variation of Brazilian propolis. Evid. Based Complement. Alternat. Med., v.2, n.1, p.33-38, 2005.

SILVA, G. M.; MAIA CAMPOS, P. M. B. G. Ascorbic acid and its derivatives in cosmetic formulations. Cosm. Toil., v.115, n.6, p.59-62, 2000a.

SILVA, G. M.; MAIA CAMPOS, P. M. B. G., 2000 b. Histopathological, morphometric and stereological studies of ascorbic acid and magnesium ascorbyl phosphate in a skin care formulation. Int. J. Cosm. Sci., v.22, n.3, p.169179, 2000b.

SALGADO-SANTOS, I. M. N.; NAKANO, A.; BABY, A. R.; VELASCO, M. V. R. Análise sensorial: ferramenta para avaliar eficácia e benefícios. Cosm. Toil., v.17, n.4, p.52$55,2005$.

TADROS, T. Application of rheology for assessment and prediction of the long-term physical stability of emulsions. Adv. Colloid Interface Sci., v.108, p.227-258, 2004.

Received for publication on $3^{\text {rd }}$ November 2010 Accepted for publication on $23^{\text {rd }}$ March 2011 